\title{
Hypothetical learning trajectory in student's spatial abilities to learn geometric transformation
}

\author{
Ricki Yuliardi ${ }^{1,2^{*}}$, Rizky Rosjanuardi ${ }^{1}$ \\ ${ }^{1}$ Department of Mathematics Education, Universitas Pendidikan Indonesia, Indonesia \\ ${ }^{2}$ Department of Mathematics Education, STKIP Muhammadiyah Kuningan, Indonesia \\ *Corresponding author: rickisyahidan27@upi.edu
}

ARTICLE INFO

Article history:

Received: 14 January 2021

Revised: 8 April 2021

Accepted: 10 April 2021

Published online: 29 June

2021

Published regularly: July 2021

\section{Keywords:}

Spatial abilities, spatial conception, geometric transformations, hypothetical learning trajectory

\section{ABSTRACT}

The relationship between spatial conceptions and students' spatial abilities is still rarely studied specifically, even though this is the basis for students to think in learning geometry. This paper aims to explore spatial abilities and the development of spatial ability theory, discusses the relationship between spatial conceptions in students' understanding, andhow to develop HLT (Hypothetical Learning Trajectory) in transformation geometry learning. HLT design consists of three stages: initial design, experimental, and retrospective analysis. The results of HLT are then refined into LIT (Local Instructional Trajectory). Then this paper present the empirical results of the perceptions of twenty 9th grade students in one of Islamic private school in Kabupaten Kuningan, West Java, Indonesia, towards the corresponding geometric and math questions. Literature review analysis was used to analyze the retrieved articles. At the end of the paper, we explain and discuss how to apply mathematical conceptions in learning geometry. This research is expected to be a guidance for teachers to develop learning in accordance with the students' spatial thinking process in studying geometry.

(C) 2021 Universitas Muhammadiyah Surakarta

\section{Introduction}

The use of the term Hypotetichal Learning Trajectory (HLT) was initiated and implemented in the process of mathematics learning by a mathematician, named Simon. Simon (2017) focused his attention on the ways teachers teach and present information to students how the flow of thinking about the concept of mathematics, as well as the creation of new experiences or problems that are designed to assist the processof better student understanding. The learning process and the level of thinking called HLT are something that must be considered in order to achieve the expected goals (Clements \& Sarama, 2011).

From the objectives stated by NCTM, it is implied that in the learning process, students build knowledge from the experiences they find in their lives (Kartianom \& Retnawari, 2018). Teachers need to see how students think about mathematics itself and relate that knowledge to experience (Retnawati, Djidu, Kartianom, Apino, \& Anazifa, 2018). Following what Ausuble stated, meaningful learning is a learning process that actively 
connects new material with students' pre-existing knowledge (Moreno \& Mayer, 1999). For that purpose, according to Clements, Gravemeijer, and Simon, it, need to conceptualize the learning trajectory as a description of children's thinking and learning in a particular mathematical domain and conceptualize an alleged route of student learning trajectories through a series of instructional tasks (Simon, 2020). Simon, Kara, Placa, and Avitzur (2018) states that HLT is a bridge between instruction theory and teaching experience in the field. In line with this, Nuraida and Amam (2019) states that HLT can be analogous to the route of the student's thought process. If we understand the possible routes to our destination, then we can choose a good route. From the HLT that has been tested, a suitable learning trajectory can be obtained and can be used to achieve the expected learning objectives.

Spatial ability is one of the human cognitive intelligences that is interesting to study because it has the potential to optimize student achievement (Buckley, Seery, \& Canty, 2018). Since the introduction of the study of psychology on spatial abilities in the 1980s, educational experts have recognized the need to integrate research in the field of psychology. This is to ascertain the various factors that affect individual mathematics learning, including those related to spatial abilities (Philip \& Presmeg, 2004). As multiple intelligences initiated by Gardner (1999), spatial abilities have an important role in studying several branches of science including mathematics, science, architectural engineering, astronomy, and others. Spatial abilities are also needed to master skills at work, for example, an architect needs spatial skills to design buildings, a mechanic needs spatial abilities to assemble or repair damaged machine parts, and much more (Lubinski, 2010; Maeda \& Yoon, 2013; Yurt \& Sunbul, 2014)

Experts have different opinions about the definition of spatial ability, but in general spatial ability refers to abilities that involve the process of receiving, storing, repeating, and transforming visually. Besides that, the gender differences are also one of the factor that affect the level of performance of spatial abilities (Diane, 2003). Moreover, the spatial ability is also defined as the basic human ability to imagine mentally, formulate visual images, and also manipulate these visual images in the mind (McGee, 1979). Previous studies by experts suggested a positive correlation between spatial abilities and higherorder thinking skills such as critical thinking and problem-solving skills (Clements \& Sarama, 2011; Hegarty \& Kozhevnikov, 1999; Kragten, Admiraal, \& Rijlaarsdam, 2015; Newcombe, 2013).

McGee (1979) formulates components of spatial abilities that have been defined and state that space, orientation, visualization, holistic (global) perception, change, speed of perception, change in perception, and figurative transformation. Parsons, Rizzo, Van Der Zaag, McGee, and Buckwalter ( $\underline{2005})$ also state that spatial aspects can be seen from spatial orientation, the memory of spatial locations, news, spatial visualization, distinguishing objects, and spatial perception. As a result of a meta-analysis of literature studies on scientific journals that study psychology and spatial abilities, Linn and Petersen ( $\underline{1985})$ classified spatial abilities into three different categories: spatial perception, spatial visualization, and mental rotation.

Spatial perception is defined as a person's ability to determine spatial relationships even though there is distracting information and can be done spontaneously by using the gravity process (for example the tilt bottle problem test and horizontal waterline to measure students' spatial perception abilities) (Linn et al., 1985). Spatial visualization is a person's ability to manipulate spatial information that is more complex and requires 
several stages to produce accurate and efficient visual images using analytical processes. Spatial visualization is also described as a person's ability to imagine the movement of objects, be it translation, reflection, or dilation of objects or their parts in 2-D and 3-D spaces mentally (Harris, Hirsh-Pasek, \& Newcombe, 2013). Spatial visualization can be measured by using the folding and opening instruments. The last one is mental rotation which is defined as a person's ability to imagine the rotation of objects 2 or 3 objects precisely and accurately. It can also be described as a brain activity that moves an object to help understand what it is and where it is by considering the point of origin, the center of rotation, and also the angle of rotation (Yüksel \& Bülbül, 2015).

Spatial ability is often believed to be related to mathematical ability (Frick, 2019; Mix, Levine, Cheng, Young, Hambrick, Ping, \& Konstantopoulos, 2016). The National Council for Mathematics Teachers (2000) has recognized the importance of introducing spatial reasoning as a mathematical approach that must be taught to children from childhood. Through the study of geometry, students will learn about geometric shapes and structures and how to analyze the characteristics and relationships between geometric shapes. the. Optimizing the spatial visualization needed to construct and manipulate mental representations of two- and three-dimensional objects and understanding objects from different perspectives is an important aspect of students' geometrical thinking. Moreover, geometry is a natural place for the development of students' reasoning and creative thinking skills, culminating in problem-solving methods in the middle class. Geometric modeling and spatial reasoning provide prospects and effective ways of interpreting and describing the physical environment and can be important tools for the relationship between spatial conceptions in students' understanding of geometric transformation concepts (NCTM, 2000). The objectives of learning geometry in NCTM can be seen in the Table 1.

Table 1

Geometry Standard Indicators from Pre-kindergarten to grade 12

\begin{tabular}{ll}
\hline No. & \multicolumn{1}{c}{ Instructional Indicators } \\
\hline 1. & $\begin{array}{l}\text { analyze the characteristics and properties of geometric shapes in two and three dimensions and can } \\
\text { explain mathematical arguments about these geometric relationships } \\
\text { determine coordinates and describe spatial relationships in geometric coordinates and other } \\
\text { representational systems; } \\
\text { apply geometric transformations using baseline coordinates (origin, axes, and angles) and } \\
\text { symmetryto analyze mathematical situations } \\
\text { 4. use visualization skills, spatial reasoning, and geometric modeling to solve problems. }\end{array}$ \\
\hline
\end{tabular}

Learning according to the NCTM standard consists of four components: tasks, discourse, learning environment, and analysis. Assigned tasks can be projects, questions, problems, constructs, applications, and exercises involving students. Discourse includes ways of presenting, thinking, speaking, agreeing, and agreeing conducted by teachers and students to discuss task completion. In giving assignments and implementing teacher discourse must create a learning environment that helps the development of students' mathematical abilities. The analysis is a reflection systematically conducted by teachers to monitor classroom activities on how good assignment, discourse, and an environment that accelerates the developmentof each student's math achievement (Nurjanah, Yuliardi, \& Luthfi, 2020).

There is a close relation between spatial abilities and studying geometry. Spatial abilities are intensely involved in creative thinking processes and at higher levels in 
studying branches of science and mathematics (Pirrone, Nicolosi, Passanisi, \& Di Nuovo, $\underline{2015}$ ). According to Sorby, Veurink, and Streiner ( $\underline{2018}$ ), children who have spatial abilities do better in science, technology, engineering, and mathematics (STEM). Studying how students think spatially in studying geometry is something very interesting. By considering the various components of spatial ability based on the literature of previous studies, we found that there is a relationship between spatial ability and understanding of geometric figures. In particular, spatial abilities are closely related to the perceptual and operative understanding of geometric figures. This motivated us to conduct further studies on how students' spatial conceptions understand the concept of geometric transformation, which includes the concepts of translation, reflection, rotation, and dilation, which require mental spatial visualization (Linn et al., 1985).

Visualization in mathematics requires special training, for example to be able to see objects in spatial space (especially three dimensions), to understand the whole configuration of relations, and to understand them as geometric objects. The basic component of visualization is visual processing (Gutiérrez, 1996). Visual processing includes the mental imaging process: a) Changes in the position of the object represented, for example translation, rotation, reflection, etc. b) Changes in the structure of the object represented, for example the dilation of the object, the image is changed in such a way that it is different from the initial shape of the object. c) Transforms the above combination of geometric objects sequentially (Borst \& Kosslyn, 2008; Poltrock \& Brown, 1984).

Several studies have been carried out in the use of the HLT method to find students' thought processes in solving mathematical problems associated with psychological aspects (Ningsih \& Paradesa, 2018; Rezky, 2019). Then previous research also shows that the spatial ability of Indonesian students in working on geometry problems still needs to be improved (Yuliardi, 2017), this is because students are not used to optimizing their spatial skills and teachers do not yet know how to develop HLT in learning mathematics in the classroom. However, there has been no previous research that applies HLT to students' spatial conceptions in understanding the concept of geometric transformations. Thus, this motivate us to find out and provide an overview of the development of HLT in students' spatial conception abilities in studying geometry material, and the results become the basis for Local Instructional Theory (LIT) which can improve student understanding in learning geometry.

\section{Research Methods}

The method used is the design research with an emphasis on the development of the HLT instrument. According to Simon (2017), HLT is defined by researchers as a goal to achieve meaningful learning according to the stage of thinking, a series of tasks to achieve goals, and predict how students think in understanding concepts by conducting retrospective analysis after learning activities. Bakker and van Eerde (2015) stated HLT design consists of three stages: the initial design, the experimental design, and the retrospective analysis. HLT is used as part of the so-called math learning cycle for one or two lessons, or even for more than two lessons. HLT can link the learning theory and concrete learning experiments.

The research subjects were twenty $9^{\text {th }}$ grade students of one of Islamic private junior high school for the 2019-2020 school year, located in Kabupaten Kuningan, West Jawa, Indonesia. HLT is used to guide the learning experiment process to understand the 
geometric transformation materialand learning hypotheses that have been determined in the form of HLT by using design research method. HLT design can be seen Figure 1.

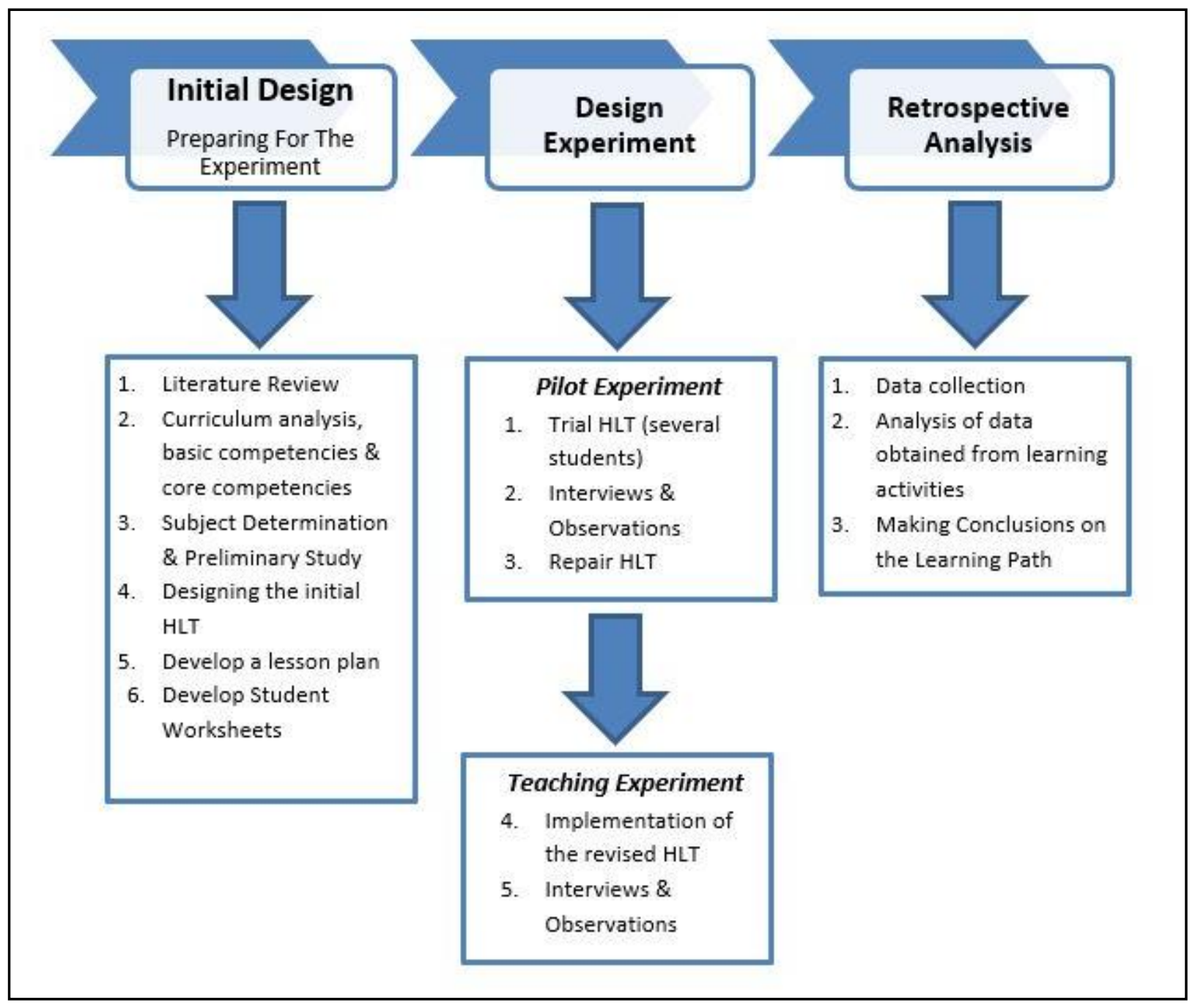

Figure 1. Hypothetical learning trajectory in mathematics learning by Simon (2017).

Phase 1 - Initial design (preparing for the experiment/preliminary)

The preliminary design aims to see the initial conditions in implementing the ideas obtained from the literature review on geometry transformation material, curriculum reviews and learning objectives. The initial research design served as the basis for formulating students' initial strategic hypotheses in learning the concept of geometric transformation. In the next step, designed the HLT which contains learning objectives, learning activities, and presumed students' way of thinking from informal stages to the formal stage (Supriatna, 2017). The trial was conducted at a private junior high school with a total of 20 students of grade 9 junior high school in Kabupaten Kuningan, West Java, Indonesia. The age range of the sample was between 14-15 years with various backgrounds consisting of 11 girls and 9 boys, this study was conducted from September to November 2020. The material studied was geometric transformation material. The first cycle was carried out by HLT testing on the Geometric Transformation material contained in the 2013 curriculum. This stage was a preliminary design trial. 


\section{Phase 2 - Design of the experiment (Teaching experiment)}

Simon (2017) states that "Mathematics Cycle" means that the teacher tries to guess (thought experiment) before carrying out learning that involves students' mental activity, then tries to find the student's actual thought process by looking at the way students understand the concept. This experimental design is divided into two experimental stages: Pilot Phase, which is the bridge between the initial design phase and the field experiment and Stages of Teaching The learning experiment which aims to answer research questions that have been previously asked. The objectives of the pilot activity are: tracing students 'basic knowledge including students' spatial conceptions in understanding geometric concepts and collecting data to support previous lesson plans.

At this stage the researcher was assisted by a mathematics teacher at the school, the results of the students' answers were analyzed to find out how students think in solving geometric transformation problems. The HLT that has been prepared is piloted in stages, starting with a pilot trial. The experimental stage of learning is carried out in large groups, the researcher acts as an observer while the teacher teaches the class. The revision of HLT to LIT (Local Instruction Theory) is carried out at this stage which is adjusted to the thinking patterns and strategies of students in the material of geometric transformation.

\section{Phase 3 - Retrospective analysis}

At this stage, the researcher reflected on learning at the teaching experiment stage. HLT that has been designed is tried out and compared with the actual student learning process to answer the formulation of research problems, while the findings in the field will be observed and recorded for the improvement of HLT. In general, the purpose of retrospective analysis is to develop LIT (Local Instruction Theory) (Bustang, Zulkardi, Darmawijoyo, Dolk, \& Van Eerde, 2013).

\section{Instrument}

The research instrument consisted of 10 questions about the concept of geometric transformation which measures 3 indicators of spatial abilities: spatial perception, spatial visualization, and spatial reasoning. The level of difficulty of the questions ranging from easy questions to difficult questions was used to measure the level of students' spatial ability in understanding the concept of geometric transformation. Instrument validation is measured by considering content validation, construct validation and face validation. Based on the results of instrument testing, the instrument is valid and can be used to measure the desired ability. Each question in this application is structured in such a way that students can imagine various ways of solving in their minds using spatial abilities when solving problems. Instruments for measuring spatial perception, spatial visualization and spatial reasoning, respectively, can be seen in Figures 2, 3 and 4 .

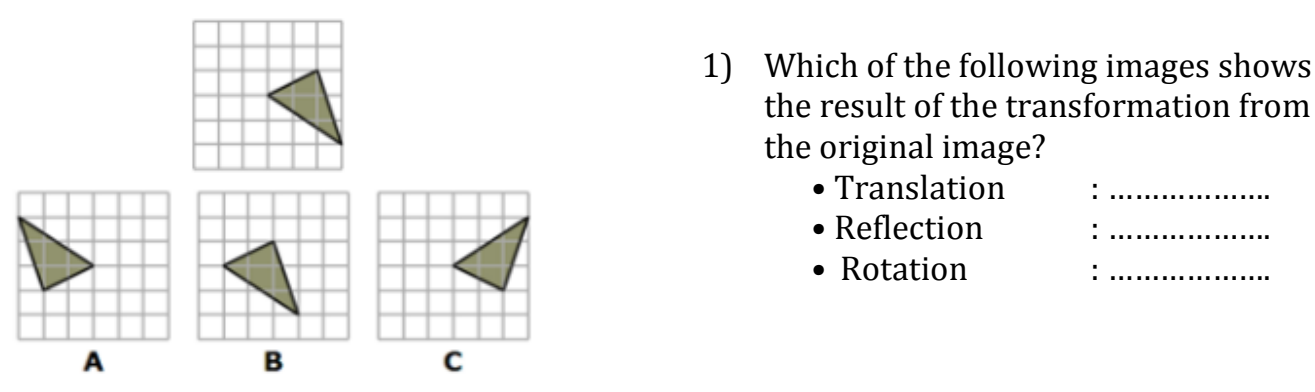

Figure 2. Spatial perception question 


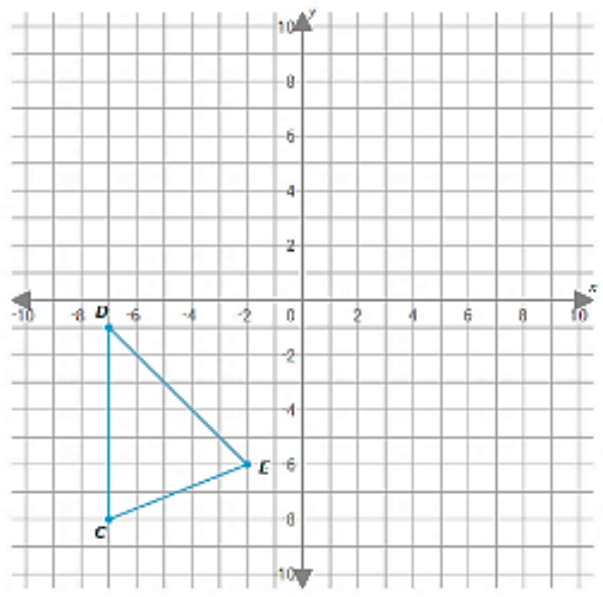

2) Draw an object's shadow according to the given transformation! (Rotation: $90^{\circ}$ clockwise to origin)

Figure 3. Spatial visualization question

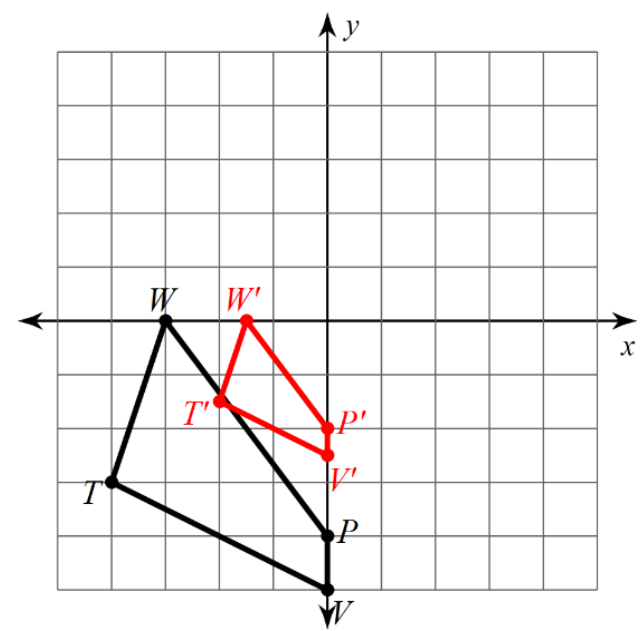

3) The image below shows an object after doing a transformation, determine what kind of transformation the object does!

Figure 4. Spatial reasoning question

\section{Results and Discussion}

This research was conducted for three weeks. The first week is the initial design stage where the researcher looked for information about literature reviews, curriculum analysis, and the development of teaching materials. The second week is the experimental design stage was through classroom observation, designing and testing the prepared HLT. HLT is obtained by interviewing students. The third week is a retrospective stage of analysis to analyze data and draw conclusions. The data of the field study is shown in Tables 2 and 3.

\section{Empirical results from research studies to explore students' perceptions of Geometric}

There are two types of data, describing students' spatial abilities in terms of gender and students' spatial abilities from the types of spatial skills developed. The description of the spatial ability score data in terms of gender can be seen in Table 2 .

Table 2

Description of the spatial ability score data in terms of gender

\begin{tabular}{lcccc}
\hline & N & Min. Score & Maks. Score & Mean \\
\hline Male & 9 & 14 & 22 & 16,44 \\
Female & 11 & 11 & 21 & 14,64 \\
\hline
\end{tabular}


Table 2 shows the minimum score for male students are 14, the maximum score is 22 with an average of 16.44 . In addition, the minimum score for female students is 11 , the maximum score is 21 with an average score of 14.64 . It is evident that the scores of male students are better than those, although it needs to be further examined through research related to differences in spatial abilities based on gender. Visually, the spatial results of the scoring ability in terms of gender can be seen in Figure 5.

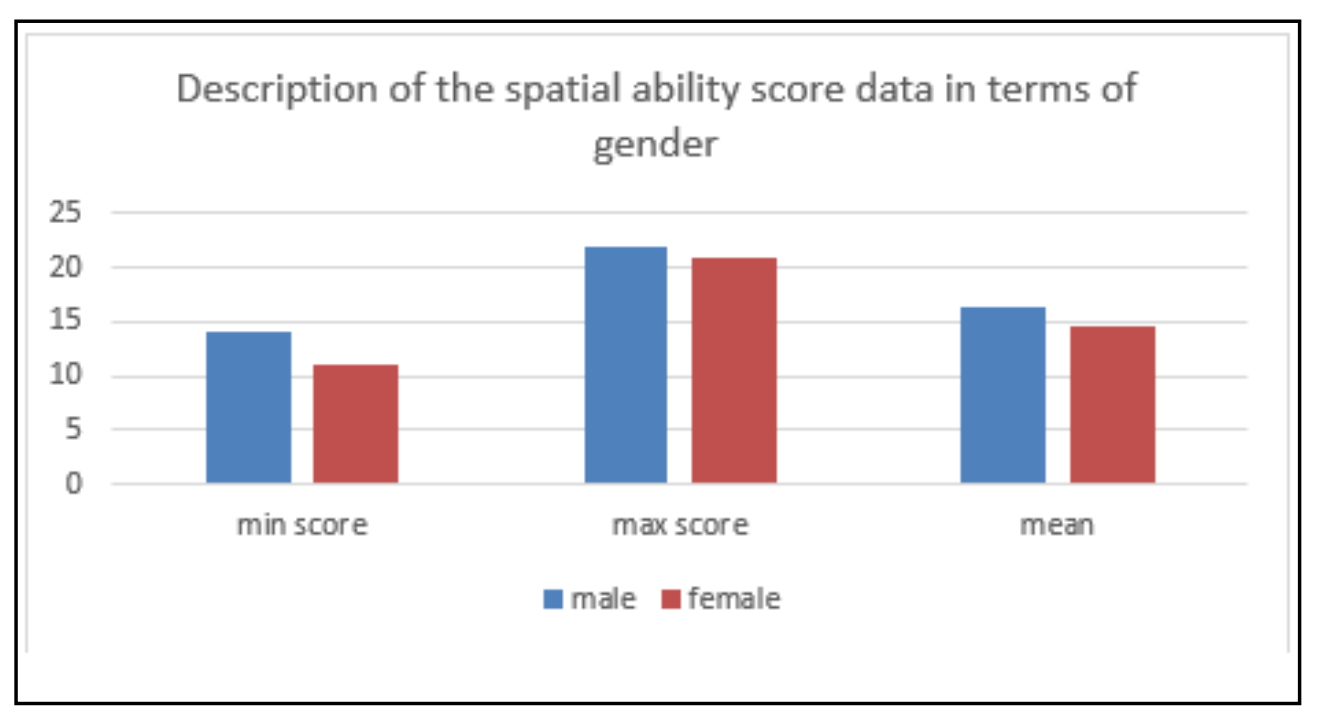

Figure 5. Description of the spatial ability score data in graphic

Whereas related to the results of student scores in terms of the types of spatial abilities needed to solve the transformation questions above can be seen in the Table 3 . Table 3 shows that there are three components of spatial ability that are measured: spatial perception, spatial visualization, and spatial reasoning. Students' scores in the aspect of spatial perception ability got the highest score with an average of 1.62 followed by spatial visualization, while in the aspect of spatial reasoning it had the lowest score with an average score of 1.42 on a scale of 3 . The description of the spatial ability score is shown in Figure 6.

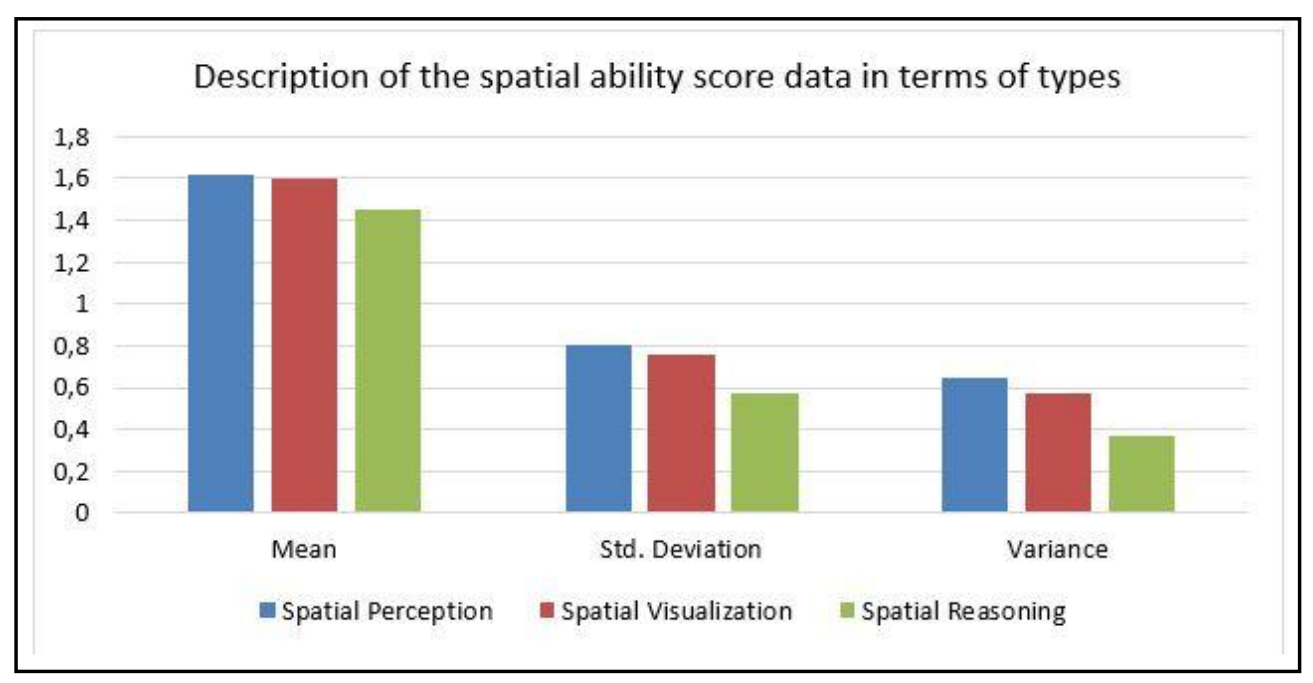

Figure 6. Graphic of the spatial ability score data in terms of types 


\section{Initial design}

Simon (2020) stated that in the first step of research design, the teacher should draw up a learning plan according to the student's learning trajectory. Lesson plans are a learning scenario compiled by the teacher based on anticipating the possibilities development of student learning for achieving learning goals based on existing knowledge owned by students and estimates students' understanding of the material (Daro, Mosher, \& Corcoran, 2011).

The core competencies and basic competencies of learning mathematics that have been compiled for geometric transformation material (The 2013 Indonesian curriculum), can be seen in Table 4 .

Table 3

Description of the spatial ability score data in terms of types

\begin{tabular}{lcccccc}
\hline & $\mathrm{N}$ & Minimum & Maximum & Mean & Std. Deviation & Variance \\
\hline Spatial Perception & 40 & 0 & 3 & 1,62 & 0,807 & 0,651 \\
Spatial Visualization & 80 & 1 & 3 & 1,60 & 0,756 & 0,572 \\
Spatial Reasoning & 80 & 1 & 3 & 1,45 & 0,571 & 0,327 \\
Valid N (Listwise) & 40 & & & & & \\
\hline
\end{tabular}

Table 4

Description of the core competencies

Core Competencies
3.5 Describe the transformation geometry
(reflection, translation, rotation, and
dilation) that is connected with the
contextual problem.

4.5 Solve contextual problem related to geometric transformations (reflection, translation, rotation, and dilation)

Indicators of Competency Achievement

a) Students can determine the image of an object resulting from there is a reflection (reflection)

b) Learners can determine the image of an object resulting from there is a translation (shift)

c) Students can determine the image of an object due to rotation (rotation)

d) Students can determine the image of an object due to dilation

a) Students can solve related contextual problems with reflection

b) Students can solve contextual problems related to translation

c) Students can solve related contextual problems with rotation

d) Students can solve contextual problems related to dilation

By reviewing the syllabus and objectives learning, drafted initial HLT transformation geometry. HLT contains three main components of learning trajectory: learning objectives to be achieved, activities that are supporting objectives, and conjectures mathematically as a result of an activity. Activities are made based on the level of students' thinking assisted with the help of media and contexts that are in accordance with the character of the students. Hypothetical learning trajectory to learning geometric transformation can be seen in Figure 7.

The HLT design is designed based on the students' thinking stages in learning the concept of geometric transformation. Based on the diagram above to achieve optimal learning objectives, students must understand the basic concepts of geometric change, the characteristics of each transformation, determine the reference point for the change 
transformation, then be able to spatially imagine the trajectory of the movement of the image of the object that changes according to the transformation carried out.

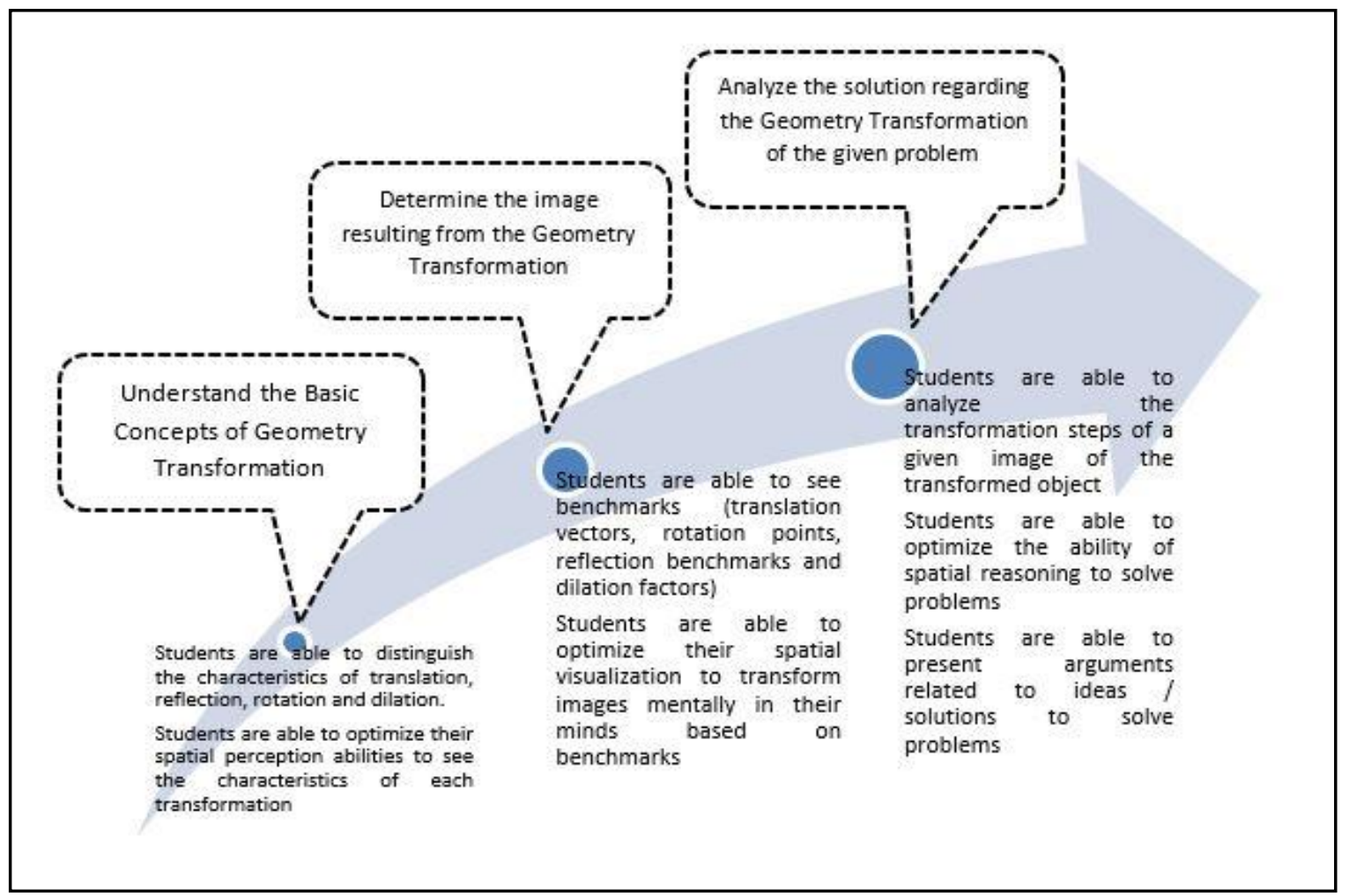

Figure 7. Hypothetical learning trajectory to learning geometric transformation

\section{Design experiment}

In the pilot experiment phase, the researcher will test the HLT design that has been made, and compare it with the conditions and thinking stages of students in the class using observations and interviews. Besides that the HLT that is designed will be revised according to the findings during learning, the implementation of this pilot experiment also adapts to the students' mathematical thinking process. Pöhler and Prediger (2015) describe six stages of the thought process through students' understanding of geometric transformation material which can be seen in Table 5 .

Table 5

Mathematical thinking process according to design experiment

\begin{tabular}{|c|c|}
\hline Process & Learning Activity \\
\hline $\begin{array}{l}\text { Level 1: } \begin{array}{l}\text { Informal } \\
\text { Stage }\end{array} \text { (starting ring } \\
\text { students' } \text { perceptions and } \\
\text { initial knowledge) }\end{array}$ & $\begin{array}{l}\text { - The teacher gives students perceptions about the relationship between } \\
\text { the concept of transformation and daily life and culture around } \\
\text { students. (For example, batik cloth patterns, Borobudur stupa) } \\
\text { - Students construct the meaning of the concept of transformation by } \\
\text { paying attention to the batik cloth pattern in an informal context }\end{array}$ \\
\hline $\begin{array}{l}\text { Level 2: The first informal } \\
\text { strategy stage (basic } \\
\text { understanding of problem- } \\
\text { solving strategies) }\end{array}$ & $\begin{array}{l}\text { - Students develop informal strategies and initial meanings that they } \\
\text { understand from previous activities (from some of the batik cloths } \\
\text { shown, students begin to understand batik patterns made in } \\
\text { translation, reflection, rotation, and dilation. }\end{array}$ \\
\hline
\end{tabular}


Table 5 (Continued)

\begin{tabular}{|c|c|}
\hline Process & Learning Activity \\
\hline $\begin{array}{l}\text { Level 3: Procedure step for } \\
\text { standard problem types }\end{array}$ & $\begin{array}{l}\text { - The teacher divides the students into groups of 3-4 students, giving } \\
\text { each student worksheets (LKS), a group containing the discovery of the } \\
\text { concept of geometric transformation } \\
\text { - } \quad \text { students define strategies to solving simple transformation problems }\end{array}$ \\
\hline $\begin{array}{l}\text { Level 4: Extending the } \\
\text { repertoire }\end{array}$ & $\begin{array}{l}\text { - The teacher gives type } 2 \text { questions where students are asked to draw } \\
\text { images of the results of the transformation by paying attention to the } \\
\text { parameters set and monitoring the activities of students in group } \\
\text { discussions } \\
\text { - Students learn to extend the strategy to other problems by performing } \\
\text { manipulations visually drawing the results of geometric } \\
\text { transformations }\end{array}$ \\
\hline $\begin{array}{l}\text { Level 5: Identifying and } \\
\text { solving different problems }\end{array}$ & $\begin{array}{l}\text { - Students Identify various types of problems (including non-standard } \\
\text { problems) in multiple contexts }\end{array}$ \\
\hline $\begin{array}{l}\text { Level 6: Flexible use of } \\
\text { concepts and strategies }\end{array}$ & $\begin{array}{l}\text { - The teacher gives questions of type 3, where students are asked to } \\
\text { analyze the steps for the transformation of an object image. } \\
\text { - Students solve a problem more complex with contexts that are unusual. } \\
\text { Each group presented the results of the discussion through a } \\
\text { presentation. This activity will encourage the emergence of new object } \\
\text { design ideas. Teachers provide reinforcement and benefits from this } \\
\text { activity. }\end{array}$ \\
\hline
\end{tabular}

\section{Retrospective analysis}

The next stage after implementing the experimental design, the retrospective analysis stage was carried out to obtain the data used as the LIT improvement, while the results of the sample students' answers are shown in the Figure 8 and 9.

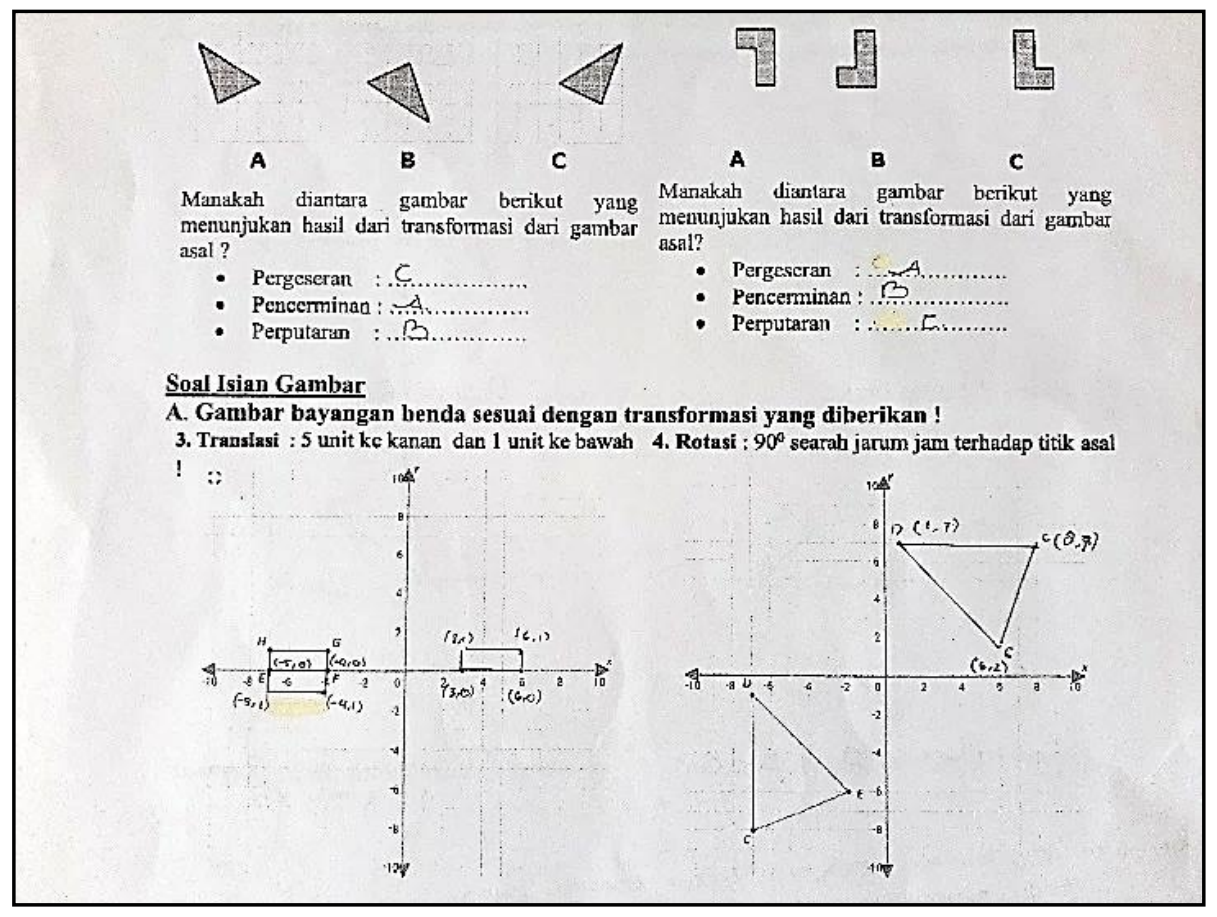

Figure 8. Students' answers to transform geometry problems 


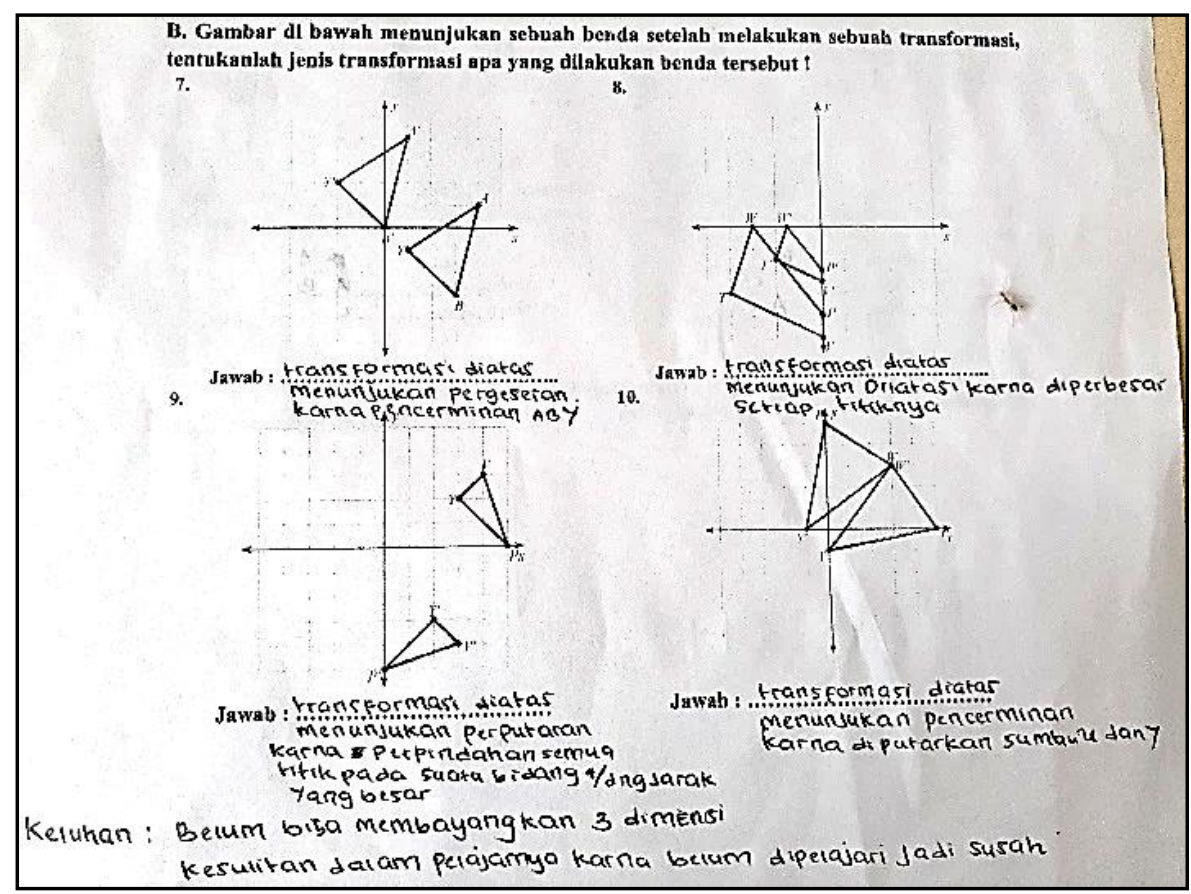

Figure 9. Students' answers to transform geometry problems

Figure 8 and 9 are an example of student answers in solving geometric transformation problems. The results of the students 'answers were deepened by interviews and then analyzed to see the students' thought processes, whether they were in accordance with the student's trajectory design, or were there interesting things that had not been achieved. This aims to see whether there is a need for improvements in teaching materials and learning strategies. From the results of the interviewin experimental design phase, it was found that students had difficulties in understanding the concept of geometric transformation, including cannot distinguish between the transformation resulting from reflection and rotation. The excerpt of the interview can be seen below.

Case 1

Teacher : Can you tell the difference between the respective types of transformation above?

Student : Yes, sir, but we are still confused about reflection and rotation

Teacher: Well you can start by comparing the characteristics of the image formed by the reflection and rotation, the same size, how the image is oriented towards the original image.

The students' difficulties above relate to the ability of spatial perception, where spatial perception is defined as the ability to determine spatial relationships even though the position of objects is changed in orientation (Linn \& Petersen, 1985). As in the example problem above students are given a picture and guess what kind of transformation is given, in this case the student still needs to practice his spatial perception in order to be able to see it flexibly. In addition, students still have difficulty determining the required attributes as a benchmark in transforming the intended shape. Student need to train their spatial perception to be able to see it flexibly, then carefully see the characteristics of the different images resulting from the transformation with its initial form. This is very important because it will be the initial process for students to think. 


\section{Case 2}

Student 1 : How come the image of my reflection with my friend is different, sir?

Teacher : Ok, try to compare the results of your work with your friends, see the standard according to the question asked, in the problem of reflecting on the line $y=x$, try to see whether you have drawn the line $y=x$ or $y=-x$ ?

Student 2 : Oh yes sir I drew it wrong, I should have used the line $y=x$

The problems found above relate to the accuracy of students in determining the standards/properties of transformation, for example, reflect this triangle $\mathrm{ABC}$ on the $x$-axis, $y$-axis or with the line $y=m x$. The standard of transformation is very important as a first step for students to think, for example, other concerning clockwise and counterclockwise rotation. Students must use the ability of spatial visualization to mentally imagine the image of the rotation, students are allowed to use tools such as arcs, rulers to measure angles and lengths from the center point to the image point, in this stage. These students have started to learn to identify a variety of different problems.

Case 3

Teacher : Take a look at the original flat image and its shadows, try to guess what transformations were made to form the image of the flat shape?

Student 1 : Sir, we can imagine it but it's hard to put it in words

Student 2 : I'm not used to mentally imagining rotation yet, I'm afraid my guess is wrong

Teacher : Try to start to note what you think little by little, use your spatial reasoning abilities, and express your ideas slowly.

The problems above are related to spatial reasoning, in this case the answers so that students can use concepts and strategies in a flexible manner, to get used to spatial reasoning, continuous and systematic training is needed. Teachers also need to use various learning media that can help students to the planned LIT. The results of this study are supported by previous research related to the application of HLT. It shows that learning with hypothetical Learning Trajectory can encourage teachers to present effective learning for students who have problems, besides that it can develop student learning skills (Ulfa \& Wijaya, 2019).

The results of the retrospective analysis propose to develop students' spatial abilities and spatial skills should have been taught to students since kindergarten, for an integrated and systematic curriculum program is needed (Uttal, Meadow, Tipton, Hand, Alden, Warren, \& Newcombe 2013). The design LIT is as follows: at the time before starting learning, the teacher should prepare learning material better by considering the aspects of students' spatial abilities, introducing the concept of geometric transformation using examples of everyday concepts, which have been known to students before, including using RME in accordance with Nuraida and Amam (2019), effective use of media, one example of the use of technology-based media. The use of technology-based learning media such as Cabri 3D and GeoGebra has been shown to improve students' spatial skills (Burte, Gardony, Hutton, \& Taylor, 2017; Sack \& Vazquez, 2011; Nurjanah, Latif, Yuliardi, \& Tamur, 2020). Besides scaffolding by teachers, it is still necessary a validmeasurement so that students can achieve the expected learning trajectory (Confrey, Toutkoushian, \& Shah, 2020). Among the three skills of spatial, spatial perception, spatial visualization, and spatial reasoning, spatial reasoning requires more attention and practice from students, get students used to mental analysis and be able to express their ideas. Meanwhile, the difference in spatial ability between genders is still interesting to continue to be researched, although there are previous studies that state that male students' spatial skills are better than female students (Reilly \& Neumann, 2013; Turgut \& Nagy-kondor, 2013). 


\section{Conclusion}

From the results of this study, it can be concluded that HLT is very important for teachers to arrange learning trajectories as a reference in designing learning that can optimize spatial skills.Especially spatial abilities that are needed for students to learn geometric concepts, although of course in this study it cannot be separated from constraintsexperienced by students from the initial initiation stage to the retrospective stage. The ideas proposed are the importance of the preparation stage of a teacher in preparing suitable teaching materials to improve students' spatial conceptions. Besides that, the use of technology-based teaching materials is needed to help students' spatial conceptions, and assistance from teachers in the learning process is still needed by students to achieve the expected learning trajectory. We expect the emergence of further research and development of innovative learning media in improving students' spatial skills by considering HLT as a reference for how students think and build geometric concept.

\section{Acknowledgment}

Special thanks, fellow researchers, and Al-Mutawally junior high school teachers in Kabupaten Kuningan who have helped collaborate to complete this research.

\section{Bibliography}

Bakker, A., \& van Eerde, D. (2015). An Introduction to Design-Based Research with an Example From Statistics Education (pp. 429-466). https://doi.org/10.1007/978-94$\underline{017-9181-616}$

Borst, G., \& Kosslyn, S. M. (2008). Visual mental imagery and visual perception: Structural equivalence revealed by scanning processes. Memory and Cognition, 36(4), 849-862. https://doi.org/10.3758/MC.36.4.849

Buckley, J., Seery, N., \& Canty, D. (2018). A Heuristic Framework of Spatial Ability: a Review and Synthesis of Spatial Factor Literature to Support its Translation into STEM Education. In Educational Psychology Review (Vol. 30, Issue 3, pp. 947-972). Educational Psychology Review. https://doi.org/10.1007/s10648-018-9432-z

Burte, H., Gardony, A. L., Hutton, A., \& Taylor, H. A. (2017). Think3d!: Improving mathematics learning through embodied spatial training. Cognitive Research: Principles and Implications, 2(1), 1-18. https://doi.org/10.1186/s41235-017-0052-9

Bustang, Zulkardi, Darmawijoyo, Dolk, M., \& van Eerde, D. (2013). Developing a local instruction theory for learning the concept of angle through visual field activities and spatial representations. International Education Studies, 6(8), 58-70. https://doi.org/10.5539/ies.v6n8p58

Clements, D. H., \& Sarama, J. (2011). Early childhood mathematics intervention. Science, 333(6045), 968-970. https://doi.org/10.1126/science.1204537

Confrey, J., Toutkoushian, E., \& Shah, M. (2020). Working at scale to initiate ongoing validation of learning trajectory-based classroom assessments for middle grade mathematics. Journal of Mathematical Behavior, 60(September), 100818. https://doi.org/10.1016/j.jmathb.2020.100818

Daro, P., Mosher, F., \& Corcoran, T. (2011). Learning Trajectories in Mathematics: A Foundation for Standards, Curriculum, Assessment, and Instruction. CPRE Research Report. Consortium for Policy Research in Education, 86. Retrieved from http://proxy- 
remote.galib.uga.edu/login?url=http://search.ebscohost.com/login.aspx?direct=true $\& \mathrm{db}=$ eric $\& A N=\mathrm{ED} 519792 \&$ site $=$ ehost-live

Diane F, H. (2003). Sex differences in cognitive abilities (3rd edition). In Applied Cognitive Psychology (Vol. 17, Issue 3). https://doi.org/10.1002/acp.883

Frick, A. (2019). Spatial transformation abilities and their relation to later mathematics performance. Psychological Research, 83(7), 1465-1484. https://doi.org/10.1007/s00426-018-1008-5

Gardner, H. (1999). Frames of Mind, Intelligence Reframed: Multiple Intelligences for The 21st Century. In New York: Basic Book.

Gutiérrez, Á. (1996). Visualization in 3-Dimensional Geometry: In Search of a Framework. Proceedings of the 20th PME Conference, 1(July 1996), 3-19.

Harris, J., Hirsh-Pasek, K., \& Newcombe, N. S. (2013). Understanding spatial transformations: Similarities and differences between mental rotation and mental folding. Cognitive Processing, 14(2), 105-115. https://doi.org/10.1007/s10339-013$\underline{0544-6}$

Hegarty, M. \& Kozhevnikov, M. (1999). Types of visual-spatial representations and mathematical problem solving. Journal of Educational Psychology, 91(4), 684-689. https://doi.org/10.1037//0022-0663.91.4.684

Kartianom, K \& Retnawari, H. (2018). Why are Their Mathematical Learning Achievements Different? Re-Analysis TIMSS 2015 Data in Indonesia, Japan and Turkey. International Journal on New Trends in Education and Their Implications, 9(2), 33-46.

Kragten, M., Admiraal, W., \& Rijlaarsdam, G. (2015). Students' Learning Activities While Studying Biological Process Diagrams. International Journal of Science Education, 37(12), 1915-1937. https://doi.org/10.1080/09500693.2015.1057775

Linn, M. C., \& Petersen, A. C. (1985). Emergence and characterization of sex differences in spatial ability: a meta-analysis. Child Development, 56(6), 1479-1498. https://doi.org/10.1111/j.1467-8624.1985.tb00213.x

Lubinski, D. (2010). Spatial ability and STEM: A sleeping giant for talent identification and development. Elsevier Personality and Individual Differences, 49(4), 344-351. https://doi.org/10.1016/i.paid.2010.03.022

Maeda, Y., \& Yoon, S. Y. (2013). A Meta-Analysis on Gender Differences in Mental Rotation Ability Measured by the Purdue Spatial Visualization Tests: Visualization of Rotations (PSVT:R). Educational Psychology Review, 25(1), 69-94. https://doi.org/10.1007/s10648-012-9215-x

McGee, M. G. (1979). Human spatial abilities: Psychometric studies and environmental, genetic, hormonal, and neurological influences. Psychological Bulletin, 86(5), 889918. https://doi.org/10.1037//0033-2909.86.5.889

Mix, K. S., Levine, S. C., Cheng, Y. L., Young, C., Hambrick, D. Z., Ping, R., \& Konstantopoulos, S. (2016). Separate but correlated: The latent structure of space and mathematics across development. Journal of Experimental Psychology: General, 145(9), 1206-1227. https://doi.org/10.1037/xge0000182

Moreno, R., \& Mayer, R. E. (1999). Cognitive principles of multimedia learning: The role of modality and contiguity. Journal of Educational Psychology, 91(2), 358-368. https://doi.org/10.1037//0022-0663.91.2.358

National Council of Teacher Mathematics. (2000). Principles Standards and for School Mathematics. Reston VA: NCTM.

Newcombe, N. S. (2013). Seeing Relationships. American Educator, 26-32. 
Ningsih, Y. L., \& Paradesa, R. (2018). Improving students' understanding of mathematical concept using maple. Journal of Physics: Conference Series, 948(1). https://doi.org/10.1088/1742-6596/948/1/012034

Nuraida, I., \& Amam, A. (2019). Hypothetical Learning Trajectory in Realistic Mathematics Education To Improve the Mathematical Communication of Junior High School Students. Infinity Journal, 8(2), 247. https://doi.org/10.22460/infinity.v8i2.p247-258

Nurjanah, Latif, B., Yuliardi, R., \& Tamur, M. (2020). Computer-assisted learning using the Cabri 3D for improving spatial ability and self- regulated learning. Heliyon, 6(July), e05536. https://doi.org/10.1016/j.heliyon.2020.e05536

Nurjanah, Yuliardi, R., \& Luthfi, A. F. (2020). Learning mathematics assisted by adobe flash software to improve mathematical reasoning ability students ongeometry concepts. Journal of Physics: Conference Series, 1567(3). https://doi.org/10.1088/1742$\underline{6596 / 1567 / 3 / 032011}$

Parsons, T. D., Rizzo, A. R., Van Der Zaag, C., McGee, J. S., \& Buckwalter, J. G. (2005). Gender differences and cognition among older adults. Aging, Neuropsychology, and Cognition, 12(1), 78-88. https://doi.org/10.1080/13825580590925125

Philip, Clarkson; Presmeg, N. (2004). Critical issues in maths edcation. In Springer. Retrieved from http://onlinelibrary.wiley.com/doi/10.1002/cbdv.200490137/ abstract

Pirrone, C., Nicolosi, A., Passanisi, A., \& Di Nuovo, S. (2015). Learning potential in mathematics through imagination and manipulation of building blocks. Mediterranean Journal of Social Sciences, 6(4S3), 152-159. https://doi.org/10.5901/mjss.2015.v6n4s3p152

Pöhler, B., \& Prediger, S. (2015). Intertwining lexical and conceptual learning trajectories A design research study on dual macro-scaffolding towards percentages. Eurasia Journal of Mathematics, Science and Technology Education, 11(6), 1697-1722. https://doi.org/10.12973/eurasia.2015.1497a

Poltrock, S. E., \& Brown, P. (1984). Individual Differences in visual imagery and spatial ability. Intelligence, 8(2), 93-138. https://doi.org/10.1016/0160-2896(84)90019-9

Reilly, D., \& Neumann, D. L. (2013). Gender-Role Differences in Spatial Ability: A MetaAnalytic Review. In Sex Roles (Vol. 68, Issues 9-10). https://doi.org/10.1007/s11199013-0269-0

Retnawati, H., Djidu, H., Kartianom, Apino, E., \& Anazifa, R. D. (2018). Teachers' knowledge about higher-order thinking skills and its learning strategy. Problems of Education in the 21st Century, 76(2), 215-230.

Rezky, R. (2019). Hypothetical Learning Trajectory (HLT) dalam Perspektif Psikologi Belajar Matematika. Ekspose: Jurnal Penelitian Hukum Dan Pendidikan, 18(1), 762 769. https://doi.org/10.30863/ekspose.v18i1.364

Sack, J. \& Vazquez, I. (2011). Development of a Learning Trajectory to Conceptualize. Conference: 35th Annual Conference of The, 1, 89-96.

Simon, M. A. (2017). Explicating mathematical concept and mathematicalconception as theoretical constructs for mathematics education research. Educational Studies in Mathematics, 94(2), 117-137. https://doi.org/10.1007/s10649-016-9728-1

Simon, M. A. (2020). Reconstructing Mathematics Pedagogy from a Constructivist Perspective. Journal for Research in Mathematics Education, 26(2), 114-145. https://doi.org/10.5951/iresematheduc.26.2.0114

Simon, M. A., Kara, M., Placa, N., \& Avitzur, A. (2018). Towards an integrated theory of 
mathematics conceptual learning and instructional design: The Learning Through Activity theoretical framework. Journal of Mathematical Behavior, 52(April), 95-112. https://doi.org/10.1016/i.jmathb.2018.04.002

Sorby, S., Veurink, N., \& Streiner, S. (2018). Does spatial skills instruction improve STEM outcomes? The answer is 'yes.' Learning and Individual Differences, 67(August), 209222. https://doi.org/10.1016/j.lindif.2018.09.001

Supriatna, T. (2017). Local Intruction Theory dalam Pendidikan Matematika Realistik untuk Menumbuhkan Kemampuan Berpikir Logis. Mimbar Pendidikan, 2(2), 173-184. https://doi.org/10.17509/mimbardik.v2i2.8627

Turgut, M., \& Nagy-kondor, R. (2013). Spatial Visualization Skills of Hungarian and Turkish Spatial Visualization Skills of Hungarian and Turkish. International Journal for Studies in Mathematics Education 6(1), 168-183.

Ulfa, C., \& Wijaya, A. (2019). Expanding hypothetical learning trajectory in mathematics instructional. Journal of Physics: Conference Series, 1320(1). https://doi.org/10.1088/1742-6596/1320/1/012091

Uttal, D. H., Meadow, N. G., Tipton, E., Hand, L. L., Alden, A. R., Warren, C., \& Newcombe, N. S. (2013). The malleability of spatial skills: A meta-analysis of training studies. Psychological Bulletin, 139(2), 352-402. https://doi.org/10.1037/a0028446

Yüksel, N. S., \& Bülbül, A. (2015). Test development study on the mental rotation ability. Anthropologist, 20(1-2), 128-139. https://doi.org/10.1080/09720073.2015. 11891732

Yuliardi, R. N. (2017). Mathematics Learning Assisted Geogebra using Technologically Aligned Classroom ( TAC ) to Improve Communication Skills of Vocational High School Student Mathematics Learning Assisted Geogebra using Technologically Aligned Classroom ( TAC ) to Improve Comm. IOP Conf. Series: Journal of Physics:, 895 012156. https://doi.org/10.1088/1742-6596/895/1/012156

Yurt, E., \& Sunbul, A. M. (2014). A Structural Equation Model Explaining 8th Grade Students' Mathematics Achievements. Educational Sciences: Theory \& Practice, August. https://doi.org/10.12738/estp.2014.4.2193 